\title{
Culture of rat cerebral oligodendrocytes in a serum-free, chemically defined medium
}

\author{
Jan W. Koper, Matthijs Lopes-Cardozo, Herms J. Romijn * and \\ Lambert M.G. van Golde \\ Laboratory of Veterinary Biochemistry, State University of Utrecht, P.O. Box 80177, 3508 TD Utrecht (The \\ Netherlands) \\ (Received October 4th, 1983) \\ (Revised January 4th, 1984) \\ (Accepted January 6th, 1984)
}

Keywords: oligodendrocyte-primary culture-serum-free medium-chemically defined medium-brain cells-rat brain

\begin{abstract}
Oligodendrocytes were isolated from the cerebra of young rats (5-10 days old) by trypsinization of the tissue followed by cell separation on Percoll gradients. The isolation was carried out in physiological, isotonic media. The cell yield was $2-4 \times 10^{6}$ cells per brain; the plating efficiency was $\geqslant 70 \%$. Isolated cells were seeded on poly-L-lysine-coated culture dishes and maintained in a serum-free, chemically defined medium for at least 30 days. After 10 days in culture $67 \pm 10 \%$ of the surviving cells were oligodendrocytes, as judged by immunocytochemical and morphological criteria, whereas most of the other cells reacted positively with antiserum against glial fibrillary acidic protein. The expression of typical oligodendrocyte markers $\left(2^{\prime}: 3^{\prime}\right.$-cyclic-nucleotide $3^{\prime}$-phosphodiesterase, galactocerebrosides and myelin basic protein) was greatly enhanced under these serum-free conditions as compared with cultures in serum-containing medium. The antigenic markers (galactocerebrosides, myelin basic protein) were absent in the freshly isolated cells but could be detected after 3 days in culture by immunocytochemistry. The activity of $2^{\prime}: 3^{\prime}$-cyclic-nucleotide $3^{\prime}$-phosphodiesterase increased from $75 \mathrm{nmol} \mathrm{min}{ }^{-1} \mathrm{mg}^{-1}$ protein on day 4 to $400 \mathrm{nmol} \mathrm{min}^{-1} \mathrm{mg}^{-1}$ protein on day 14 in culture.
\end{abstract}

\section{Introduction}

Oligodendrocytes produce myelin in the central nervous system. Isolation and maintenance in culture of this cell type is therefore of great importance for the biochemical investigation of the synthesis of myelin-specific compounds and their assembly in myelin membranes. Several procedures have been described for the

\footnotetext{
* Present address: Netherlands Institute for Brain Research, IJdijk 28, 1095 KJ Amsterdam, The Netherlands.

Correspondence: J.W. Koper, Laboratory of Veterinary Biochemistry, State University of Utrecht, P.O. Box 80177, 3508 TD Utrecht, The Netherlands.
}

0165-0270/84/\$03.00@1984 Elsevier Science Publishers B.V. 
isolation of oligodendrocytes; some are only intended for the bulk isolation of these cells (Poduslo and Norton, 1972), whereas other methods have been developed with the aim of obtaining a pure culture of oligodendrocytes (McCarthy and de Vellis, 1980: Hirayama et al., 1983).

Our aim was the isolation of metabolically active oligodendrocytes which could be maintained in a serum-free, chemically defined culture medium so as to study their lipid metabolism. Such media are advantageous for the investigation of the metabolic effects of hormones. Serum-free media for primary cultures of neural cells have been used previously (e.g. Honneger et al., 1979; Snyder and Kim. 1979; Morrison and de Vellis, 1981; Romijn et al., 1982; Brunner et al., 1982).

This paper describes a method for the isolation of an oligodendrocyte-enriched cell population from the brains of rat pups. The cells can be maintained in culture for at least one month in a chemically defined medium and express specific oligodendrocyte markers (see Mirsky et al., 1980), such as galactocerebrosides, myelin basic protein and $2^{\prime}: 3^{\prime}$-cyclic-nucleotide $3^{\prime}$-phosphodiesterase (EC 3.1.4.37) to a greater degree than cells cultured in serum-containing medium.

\section{Materials and methods}

\section{Materials}

Putrescine and biotin were obtained from Serva (Heidelberg, F.R.G.); Percoll was supplied by Pharmacia (Uppsala, Sweden). Goat anti-rabbit-IgG conjugated to fluoroisothiocyanate (FITC) was bought from Miles-Yeda (Rehovot, Israel). Rabbit anti-galactocerebroside serum was prepared by injecting rabbits with an emulsion of galactocerebrosides (Type I, Sigma, St. Louis, MO), bovine serum albumin (Sigma A 8022) and complete Freund's adjuvant, following the procedure described by Bologa et al. (1981). Dulbecco's Modified Eagle Medium (DMEM) was purchased from Gibco (Grand Island, NY); Ham's F12 medium and Newborn Calf Serum (Lot no. 29101128) were obtained from Flow (Irvine, U.K.). Deoxyribonuclease (D0751), trypsin (T 8253), soybean trypsin-inhibitor (Type II-S), poly-L-lysine (P 2636) and all other biochemicals were supplied by Sigma (St. Louis, MO). Albumin was further purified as described by Chen (1967).

\section{Animals}

Wistar rats, 13 days pregnant, were obtained from the Central Institute for the Breeding of Laboratory Animals (Zeist, the Netherlands). The litters were trimmed to 10 pups one or two days after birth. Five-to-10-day-old pups were used for the isolation of oligodendrocytes.

\section{Isolation of oligodendrocytes}

The procedure described here combines two methods (Snyder et al., 1980; Gebicke-Harter et al., 1981; see also Hirayama et al., 1983). The procedure is carried out at room temperature under sterile conditions. Ten pups were decapitated and the heads were immersed in $70 \%$ ethanol, washed with Hank's balanced salts solution 
(HBSS, without $\mathrm{CaCl}_{2}, \mathrm{MgCl}_{2}$ and $\mathrm{NaHCO}_{3}$, but with $5 \mathrm{mM}$ HEPES and 100 $\mathrm{U} / \mathrm{ml}$ penicillin and $100 \mu \mathrm{g} / \mathrm{ml}$ streptomycin). The cerebra were removed and collected in HBSS, transferred to a dry Petri dish and subsequently minced to pieces of about $1 \mathrm{~mm}^{3}$ in $0.5 \mathrm{ml}$ of HBSS containing $0.5 \mathrm{mg}$ of deoxyribonuclease. The mince was dispersed in $40 \mathrm{ml}$ of HBSS containing $60 \mathrm{mg}$ trypsin and transferred to a $100 \mathrm{ml}$ flask which was shaken during $45 \mathrm{~min}$ at $37^{\circ} \mathrm{C}$. Subsequently the suspension was centrifuged for $2 \mathrm{~min}$ at $275 \mathrm{~g}$. After removal of the supernatant and the superficial layer of red blood cells, the remaining tissue was washed twice with HBSS and finally suspended in $10 \mathrm{ml}$ of HBSS containing $30 \mathrm{mg}$ soybean trypsin inhibitor and $0.5 \mathrm{mg}$ deoxyribonuclease. The tissue was then dissociated carefully by pipetting with a glass $10 \mathrm{ml}$ pipette (orifice approx. $0.5 \mathrm{~mm}$ ) until clumps of tissue were no longer visible (10-20 passes). The obtained cell suspension was sieved through a double layer of nylon screen ( $100 \mu \mathrm{m}$ pores), adding HBSS to facilitate the sieving, to a final volume of $90 \mathrm{ml}$. This suspension was then mixed with $30 \mathrm{ml}$ of undiluted Percoll.

Six "step-gradients" were prepared by layering $15 \mathrm{ml}$ of a $20 \%$ Percoll dilution in HBSS over $20 \mathrm{ml}$ of the cell suspension (25\% Percoll) (see Fig. 1). The gradients were centrifuged during $30 \mathrm{~min}$ at $9150 \mathrm{~g}_{\max }$ in a Sorvall GSA rotor using special adaptors for $50 \mathrm{ml}$ tubes. After centrifugation the top $15 \mathrm{ml}$, including the floating layer of debris and dead cells, were removed by suction. The distinct band of red blood cells at the bottom (Fig. 1) was removed using a Pasteur pipette. The remaining suspension of cells (about $20 \mathrm{ml}$ per tube) was sieved through nylon screen $(20 \mu \mathrm{m}$ pores) and diluted with 3 volumes of HBSS. The cells were then pelleted by centrifugation $\left(10 \min\right.$ at $1465 g_{\max }$ ) in a Sorvall GSA rotor. The supernatant was removed, and the cell pellet was suspended in DMEM containing 10\% (v/v) newborn calf serum. An appropriate dilution of the cell suspension was counted using a hemocytometer under a phase contrast microscope. The yield was usually between 2 and $4 \times 10^{6}$ cells per brain. The whole procedure took $3.5-4 \mathrm{~h}$.

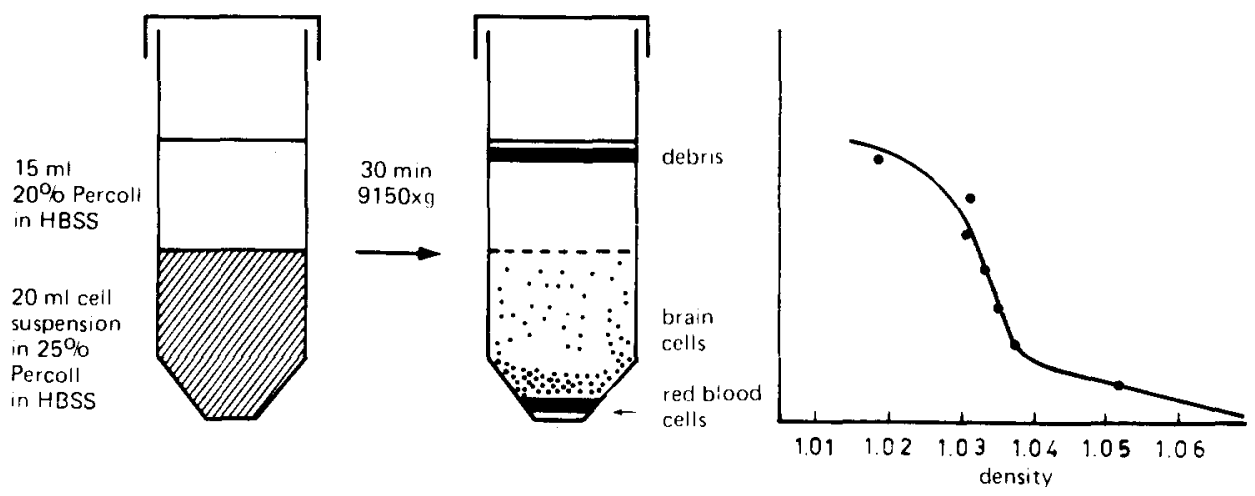

Fig. 1. Step-gradient centrifugation, showing the position of debris, red blood cells and brain cells and the change in density profile resulting from centrifugation. 
Culture conditions

Cells were plated in plastic tissue culture dishes (Nunc, Denmark) that had been coated with poly-L-lysine $\left(5 \mu \mathrm{g} / \mathrm{ml} ; 0.1 \mathrm{ml} / \mathrm{cm}^{2}\right)$ for $1 \mathrm{~h}$ and air dried. The cell density was $3 \times 10^{4}$ cells per $\mathrm{cm}^{2}$ in $1.5 \mathrm{ml}$ DMEM $\left(0.15 \mathrm{ml} / \mathrm{cm}^{2}\right)$ containing final concentrations of $10 \%$ newborn calf serum, $25 \mathrm{mM}$ glucose, $4 \mathrm{mM}$ glutamine, 100 $\mathrm{U} / \mathrm{ml}$ penicillin, $100 \mu \mathrm{g} / \mathrm{ml}$ streptomycin, $20 \mathrm{mM}$ HEPES and $8 \mathrm{mM}$ sodium bicarbonate. The medium was replaced after $24 \mathrm{~h}$ by $1.5 \mathrm{ml}$ of a new chemically defined medium (CDM; Table I) developed by Romijn et al. (unpublished results) on the basis of the hormone-supplemented medium formulated by Bottenstein and Sato (1979). Cytosine-1- $\beta$-D-arabinoside (Ara-C; $10^{-5} \mathrm{M}$ ) was added after another day in culture. Ara-C $\left(10^{-5} \mathrm{M}\right)$ was also added when the medium was changed after 5 days in vitro. Subsequently the medium was changed every 4 days. The cultures were maintained at $37^{\circ} \mathrm{C}$ in a water-saturated atmosphere of $95 \%$ air and $5 \% \mathrm{CO}_{2}$.

\section{Immunofluorescence}

Cultures were washed 3 times with HBSS (which was also used for all further washes), followed by a $30 \mathrm{~min}$ incubation at room temperature with $4 \%$ formaldehyde in HBSS. After fixation the cultures were washed again 3 times. Before incubation with the antisera against myelin basic protein and glial fibrillary acidic

TABLE I

COMPOSITION OF THE CHEMICALLY DEFINED MEDIUM

\begin{tabular}{lc}
\hline DMEM:Ham's F12: $\mathrm{H}_{2} \mathrm{O}^{*}$ & $67.5: 22.5: 10$ \\
\hline Ascorbic acid & $50.0 \mathrm{mg} /$ liter \\
Biotin & 0.1 \\
Bovine serum albumin (approx.) & $23 \times 10^{3}$ \\
DL-Carnitine & 2.0 \\
D-(+)-Galactose & 7.5 \\
Glutamine & 33.0 \\
Hydrocortisone & $20.0 \times 10^{-3}$ \\
Insulin & 2.0 \\
linolenic acid ** & 1.0 \\
linolenic acid ** & 1.0 \\
Na ${ }_{2}$ SeO & $7.9 \times 10^{-3}$ \\
Progesterone & $6.3 \times 10^{-3}$ \\
Putrescine & $16.0 \times 10^{-3}$ \\
Retinol $* *$ & 0.1 \\
Retinyl acetate $* *$ & 0.1 \\
DL- $\alpha$-Tocopherol $* *$ & 1.0 \\
DL- $\alpha$-Tocopheryl acetate $* *$ & 1.0 \\
Transferrin & 50.0 \\
Triiodothyronine & $2.0 \times 10^{-3}$ \\
\hline
\end{tabular}

* The final glucose concentration was $20 \mathrm{mM}$; HEPES $(20 \mathrm{mM}), \mathrm{NaHCO}_{3}(8 \mathrm{mM})$, penicillin $(100$ $\mathrm{U} / \mathrm{ml})$ and streptomycin $(100 \mu \mathrm{g} / \mathrm{ml})$ were added. Final $\mathrm{pH}$ at $37^{\circ} \mathrm{C}$ was 7.4 . Water was added to bring the osmolarity of the medium to $300 \mathrm{mOsm}$.

** As their albumin complexes at molar ratios of 0.2 (retinol, retinyl acetate), 1.6 (tocopheryl, tocopheryl acetate) and 5 (fatty acids). 
protein, the cultures were incubated for 10 min with a $0.1 \%$ solution of Nonidet $P_{40}$ in HBSS, followed by three washes. For incubation with anti-galactocerebroside serum, fixed or unfixed cultures were used without further treatment. They were incubated with the antisera for $30 \mathrm{~min}$ at room temperature followed by 3 washes. The cultures were then incubated for $30 \mathrm{~min}$ with goat anti-rabbit-IgG FITC conjugate and washed again. Stained cultures were inspected with a Zeiss microscope with FITC-fluorescence and phase-contrast optics.

\section{Other methods}

$2^{\prime}: 3^{\prime}$-Cyclic-nucleotide $3^{\prime}$-phosphodiesterase (EC 3.1.4.37) was measured in homogenates of rat cerebra and in sonicates of cultured cells using the method described by Sims and Carnegie (1978). Protein was estimated using the method of Lowry et al. (1951).

\section{Results}

\section{Development of cells in culture}

The procedure for cell isolation, described in this paper, gives a yield between 2 and $4 \times 10^{6}$ cells per cerebrum. The cells attach very rapidly to the bottom of the poly-L-lysine-coated culture dishes. On uncoated dishes this attachment is delayed, so that cells clump together and are lost when the medium is changed. Aggregation also occurred when the cells were seeded too densely.

The percentage of cells that remains attached after $24 \mathrm{~h}$ is variable (70-90\%) and depends at least partially on the age of the animals.

The development of the cultures varies with the composition of the culture medium: in DMEM $/ 10 \%$ newborn calf serum the cells develop a morphology, as seen by phase optics, which is similar to the astrocyte-enriched cultures described by Hansson et al. (1980). Surprisingly, more than $90 \%$ of the cells in our preparation were glial fibrillary acidic protein negative and only few galactocerebroside-positive cells were present (cf. Raff et al., 1983). After 10-14 days in culture, small, phase-dark cells appear on top of the confluent cell layer; after this time the appearance of the culture remains constant (Fig. 2). Similar cells have been observed by McCarthy and de Vellis (1980). In our culture system the small dark cells remain galactocerebroside-negative. However, the activity of cyclic-nucleotide phosphodiesterase increased with the age of the culture (from $20 \mathrm{nmol} \mathrm{min}-1 \mathrm{mg}^{-1}$ at 3 days in vitro to $150 \mathrm{nmol} \mathrm{min}{ }^{-1} \mathrm{mg}^{-1}$ protein at 14 days in vitro). Because cyclic-nucleotide phosphodiesterase activity is very high in brain and preferentially associated with myelin and myelin-related cellular structures (see Sprinkle et al., 1980; Nishizawa et al., 1981; Pfeiffer et al., 1981; Hansson et al., 1982; and refs. therein), this result might indicate that precursor cells of oligodendrocytes do develop in the presence of serum, expressing cyclic-nucleotide phosphodiesterase activity but lacking galactocerebrosides. Hansson et al. (1982) showed that the cyclic-nucleotide phosphodiesterase activity is low in astrocyte cultures and does not increase with the age of the culture. 


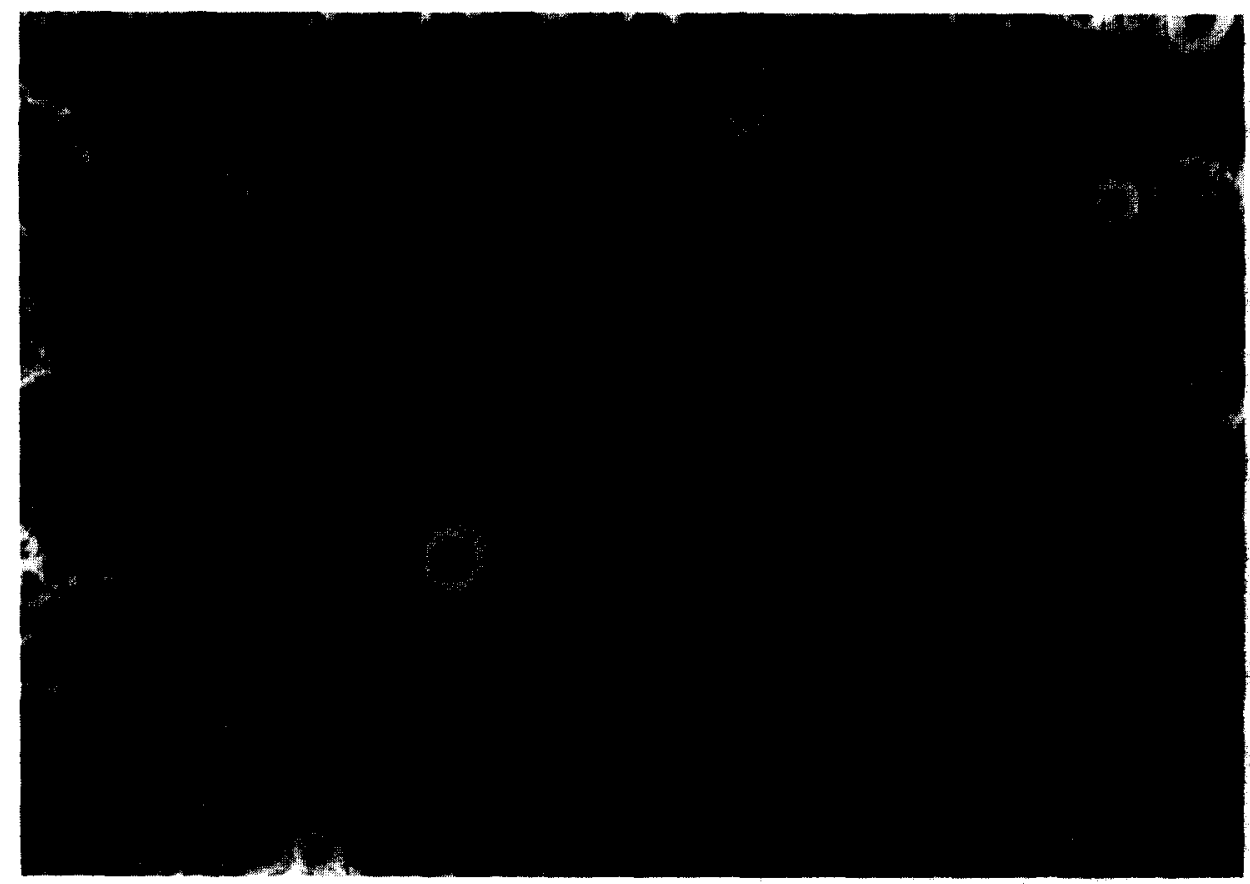

Fig. 2. Culture of brain cells in DMEM $/ 10 \%$ newborn calf serum after 28 days in culture. Note the confluent layer of cells with small dark cells on top.

We plated our cells in serum-containing medium because the cultures deteriorated gradually if plated directly in CDM. The cells developed quite differently when the DMEM $/ 10 \%$ newborn calf serum was replaced by CDM after $24 \mathrm{~h}$. After $48 \mathrm{~h}$ in vitro two main cell types predominated (Fig. 3). The most abundant is a cell type that develops a very elaborate and highly branched system of processes, which became increasingly complex with the age of the culture (Figs. 4 and 5). These cells are galactocerebroside-positive (Fig. 6) and myelin basic protein positive (Fig. 7). Using anti-galactocerebroside serum, the processes were more intensely fluorescent, whereas anti basic-protein fluorescence was observed predominantly in the perikarya. The oligodendrocytes make up $67 \pm 10 \%$ of the cells after 10 days in culture. Most of the other cells were astrocytes (glial fibrillary acidic protein positive).

These astrocytes proliferated in CDM, but more slowly than in serum-containing medium. In addition to oligodendrocytes and astrocytes, a small number of phagocytic cells was usually present, as judged by the uptake of Indian ink. Hansson et al. (1980) also reported the presence of macrophages in their primary cultures. Initially some small bipolar cells also developed but they disappeared after 7-10 days in vitro. We do not know if this is a population of neurons or of oligodendrocyte precursor cells as reported by Raff et al. (1983).

The activity of cyclic-nucleotide phosphodiesterase increased from $75 \mathrm{nmol} \mathrm{min}{ }^{-1}$

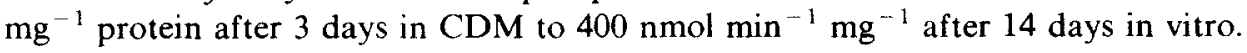




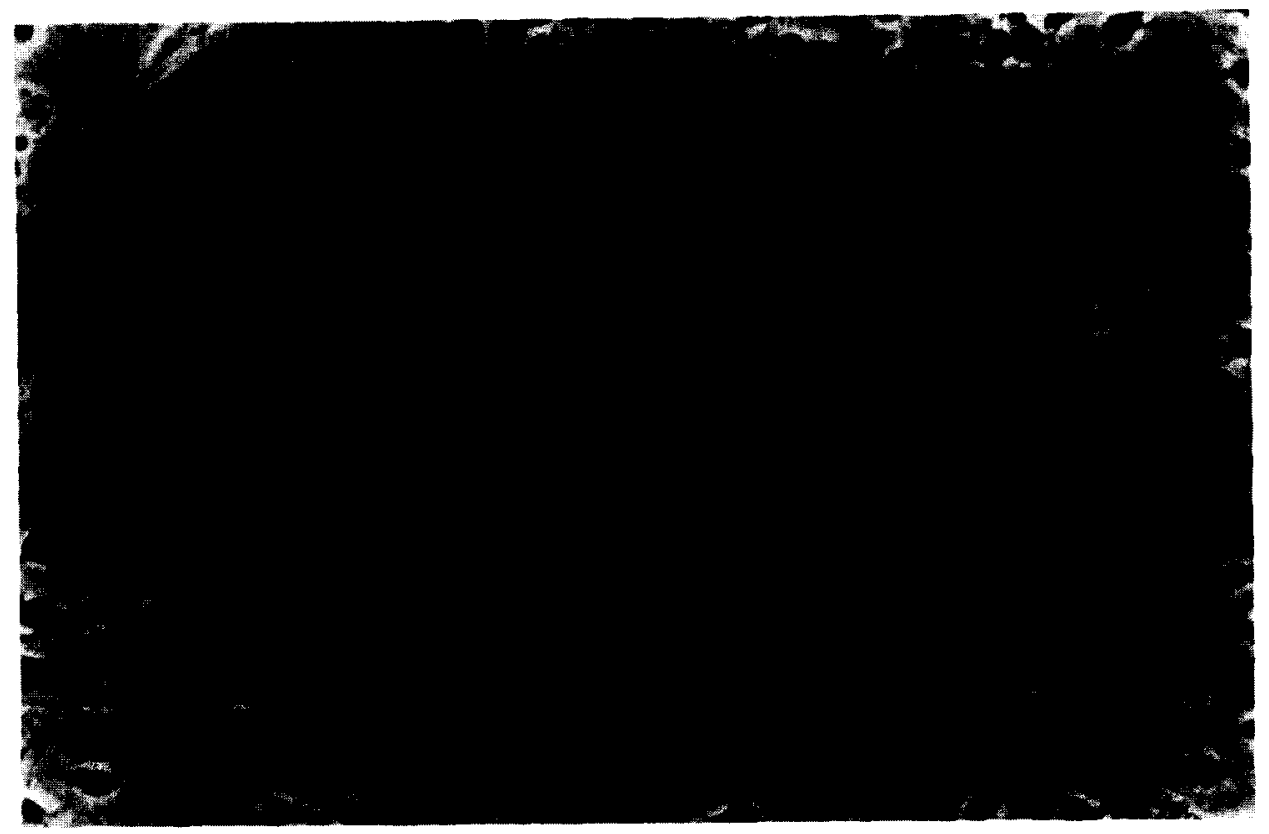

Fig. 3. Culture of brain cells after 2 days in vitro. Two cell types have become apparent: flat, elongated cells and small round cells that bear many processes. The cells were seeded in DMEM $/ 10 \%$ newborn calf serum. After $24 \mathrm{~h}$ this medium was replaced by CDM. (For further culture conditions see Methods section.)

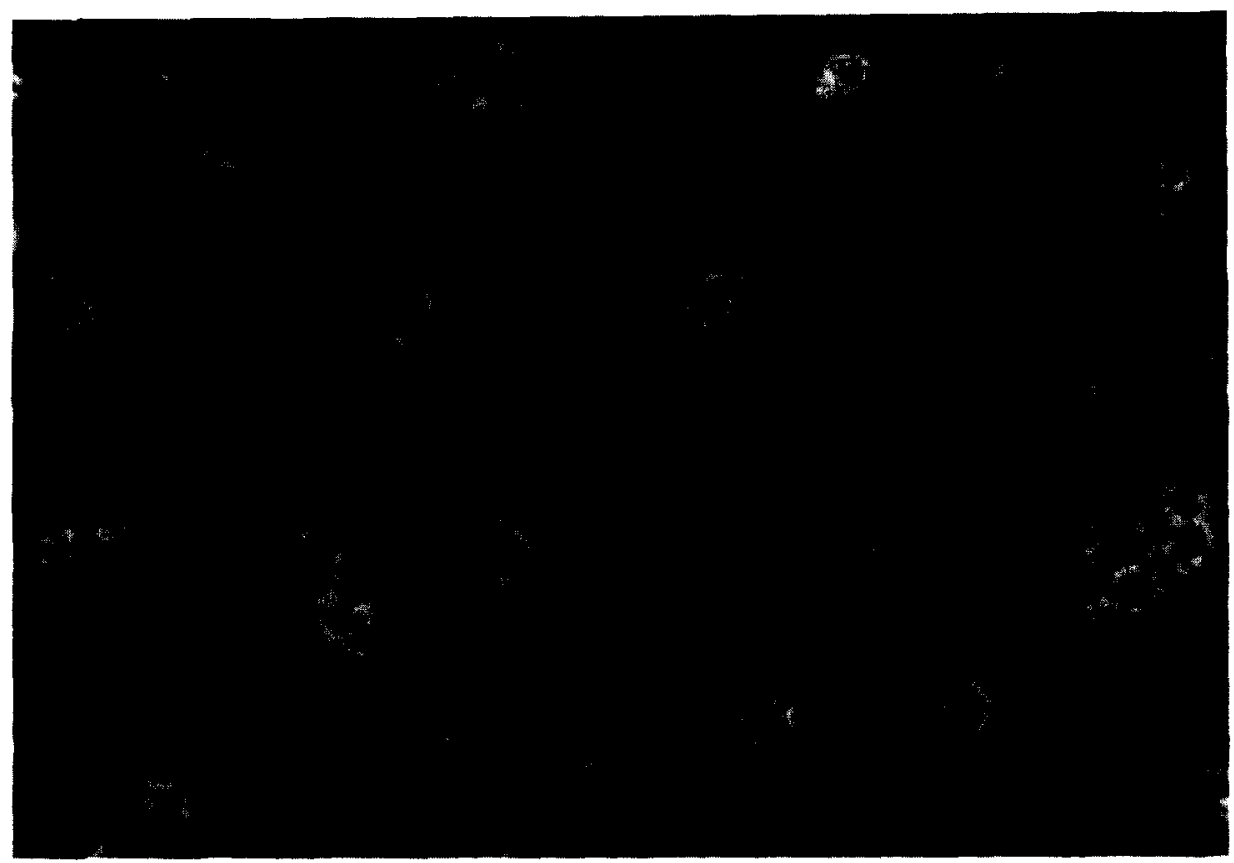

Fig. 4. Culture of brain cells, 4 days after isolation. Note the highly branched oligodendrocytes, interspersed with astrocytes. The cells were seeded in DMEM/10\% newborn calf serum. After 24 h this medium was replaced by CDM. After $48 \mathrm{~h}$ Ara-C was added. (For further culture conditions see Methods section.) 


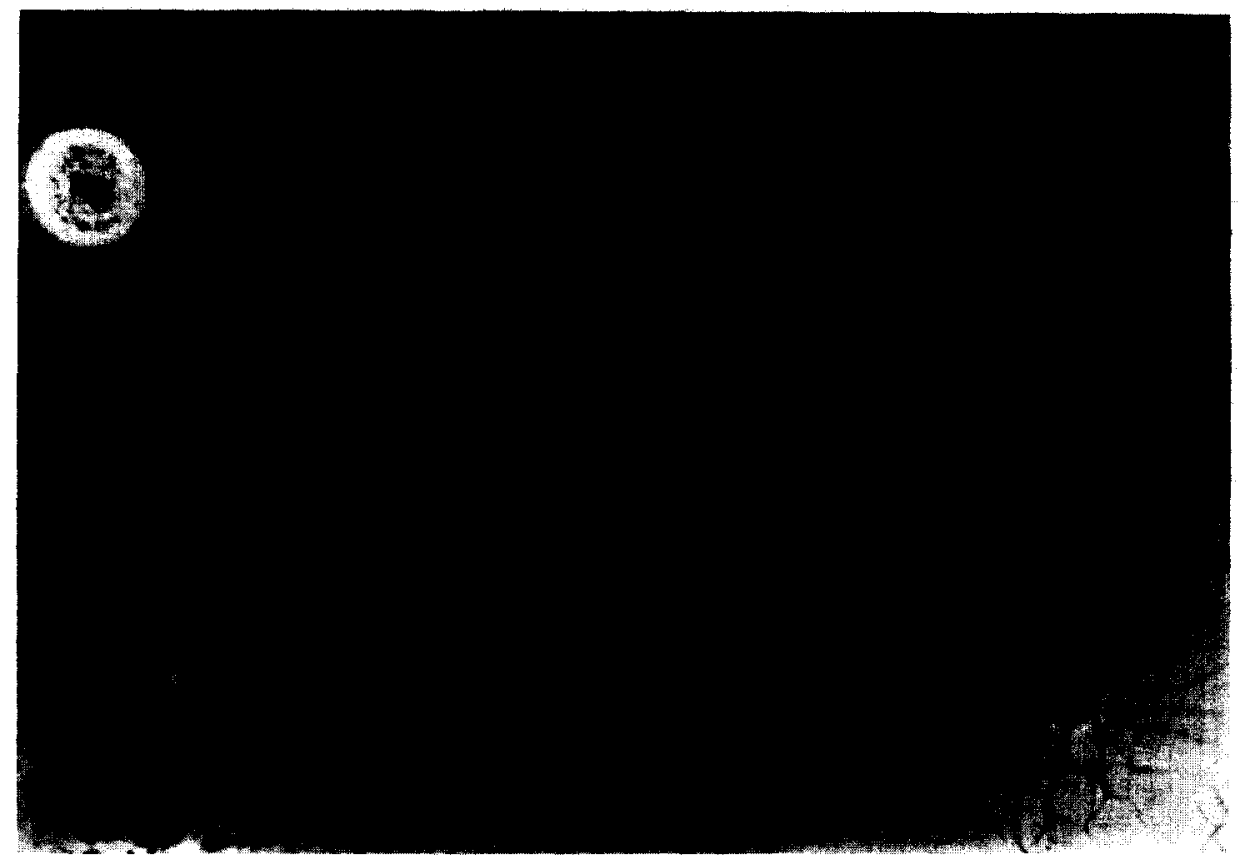

Fig. 5. Oligodendrocytes after 10 days in culture. The cells were seeded in DMEM/10\% newborn calf serum. After $24 \mathrm{~h}$ this medium was replaced by CDM. After $48 \mathrm{~h}$ Ara-C was added. (For further culture conditions see Methods section.)

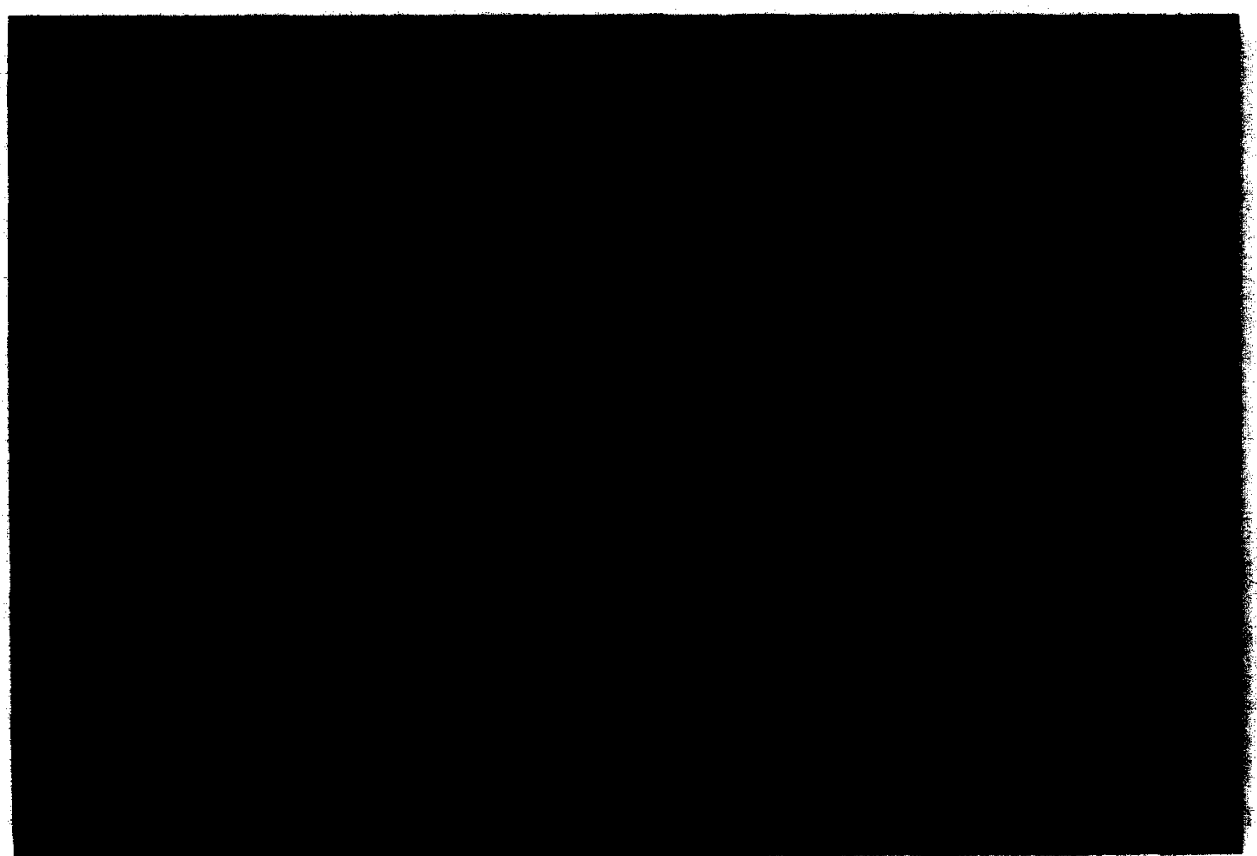

Fig. 6. Oligodendrocytes fixed and stained for galactocerebroside by the indirect fluorescent antibody technique. 


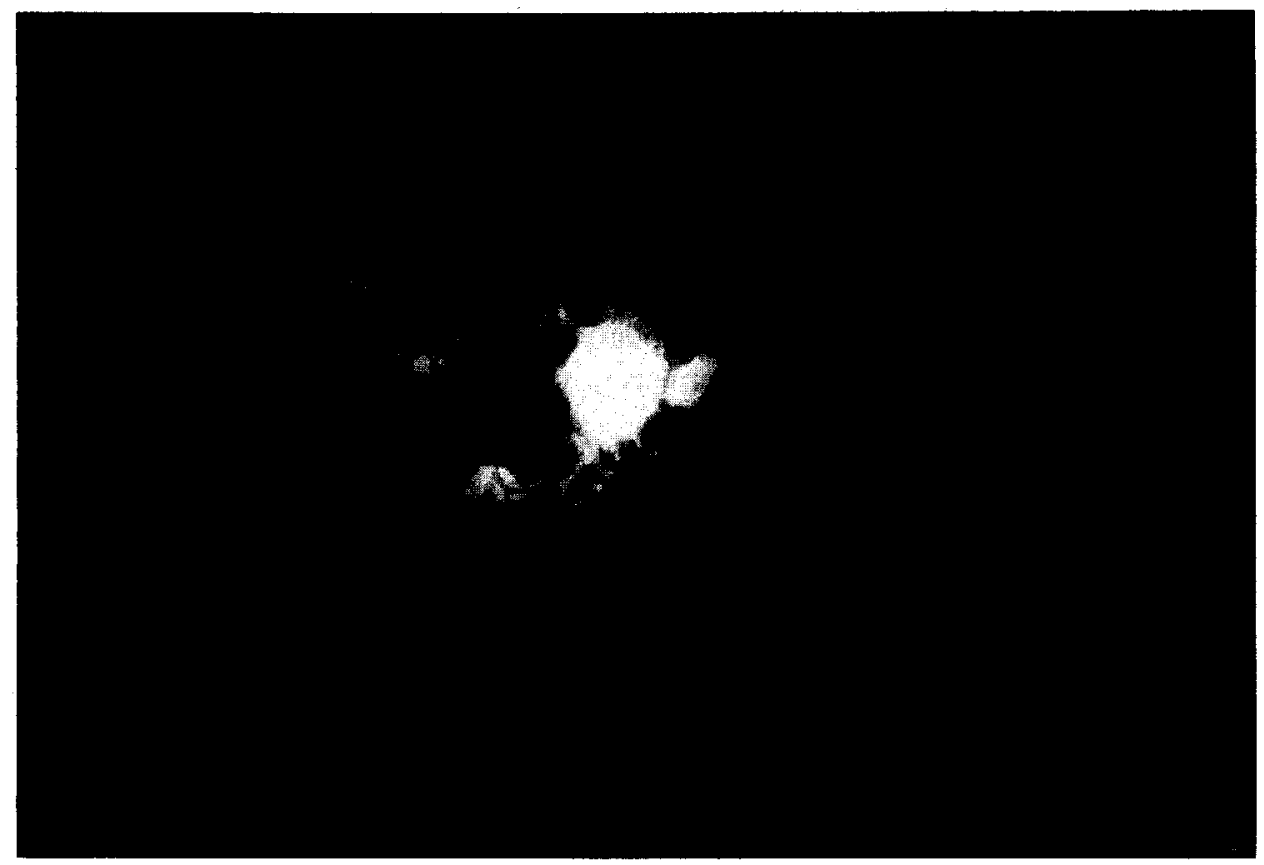

Fig. 7. Oligodendrocytes fixed and stained for myelin basic-protein by the indirect fluorescent antibody technique.

Parallel experiments showed that cyclic-nucleotide phosphodiesterase activity in whole cerebrum homogenates increased from $100 \mathrm{nmol} \mathrm{min}{ }^{-1} \mathrm{mg}^{-1}$ protein at day 6 to 1000 at day 21.

An interesting observation was that oligodendrocytes in CDM tended to form domains in culture (see Fig. 4); preferably in the open spaces between proliferating astrocytes. Apparently oligodendrocytes produce a more elaborate network of processes when they are attached directly to the coated surface of the dish than when they grow on top of a layer of astrocytes.

Cultures were maintained during at least 30 days. However, the percentage of oligodendrocytes slowly decreased due to astroglial overgrowth.

\section{Discussion}

Oligodendrocytes are the cells that produce and maintain myelin in the central nervous system (reviewed by Norton, 1983). In rat pups, myelination peaks at the end of the suckling period, in the third postnatal week. Myelin has a high lipid content with cholesterol, phospholipids and galactocerebrosides in a molar ratio of $4: 3: 2$. Hence it can be anticipated that oligodendrocytes have a high capacity for lipid synthesis. Dissociation of brain tissue into isolated cells results in the rupture of 
processes, tight junctions etc. As a consequence, it is essential that the isolated cells are allowed to recover in culture from this sustained damage, before their metabolic properties are investigated. Moreover, long-term cultures will be required for the study of myelination, which is not a short-term process. A successful cell isolation method should, therefore, employ physiological conditions in order to maintain viability both during the isolation procedure and the subsequent culture. To achieve this goal, oligodendrocytes were isolated just before the stage of active myelination, but after the development of sufficient oligodendrocyte precursor cells (Raff et al., 1983) that will continue their development in vitro.

A number of reports on the isolation of oligodendrocytes has been published during the last decade (e.g. Poduslo and Norton, 1972; Fewster et al., 1973; Chao and Rumsby, 1977; Szuchet et al., 1978; Snyder et al., 1980; McCarthy and de Vellis, 1980; Bhat et al., 1981; Lisak et al., 1981; Gebicke-Harter et al., 1981; Hirayama et al., 1983). As far as rat-brain oligodendrocytes are concerned, the method described by McCarthy and de Vellis (1980) is the only one using physiological conditions as much as possible and yielding enough cells for biochemical investigations. Bhat et al. characterized oligodendrocytes isolated by a modification of this procedure and reported a purity of 99\%. A drawback of this method is, that the primary cultures must be maintained for two weeks, before oligodendrocytes can be harvested and subcultured. This precludes the study of the early steps in the differentiation of oligodendrocytes and myelination. Other authors use unphysiological media, e.g. hypertonic sucrose gradients for cell separation (Szuchet et al., 1978; Snyder et al., 1980). More recently iso-osmotic Percoll gradients were introduced for the isolation of oligodendrocytes from cat brain (Gebicke-Harter et al., 1981), bovine brain (Lisak et al., 1981) and rat brain (Hirayama et al., 1983). The isolation method described in this paper uses physiological media and isotonic gradients and yields an oligodendrocyte-enriched culture with cells that exhibit typical oligodendrocyte markers within 3 days after isolation. The age of the rat pups (5-10 days old), is critical for the quality of the preparation. If older rats were used, the yield and viability dropped rapidly; from younger rats oligodendrocytes could also be isolated, but the purity of the preparation was lower.

The most important feature of our method is the utilization of a new serum-free culture medium (CDM) which was recently formulated for the growth of cerebral cortex neurons by Romijn (unpublished results). Since the pioneering work by the group of Sato (see Barnes and Sato, 1980), serum-free, hormone-supplemented culture media have been used also for the culture of neural cells (Honneger et al., 1979; Snyder and Kim, 1979; Morrison and de Vellis, 1981; Romijn et al., 1982; Brunner et al., 1982). One of the advantages of a chemically defined medium over a serum-containing medium is the possibility to study quantitatively and reproducibly the influence of hormones upon myelination. Studies on cellular secretion products and intercellular messengers might be facilitated in serum-free media because it has been suggested that serum possibly interferes with these processes (Bhat et al., 1981). The expression of oligodendrocyte-specific markers indicates that the early development of oligodendrocytes in this CDM parallels their development in vivo (see also Abney et al., 1981 and Hansson et al., 1982). The further development of oligo- 
dendrocytes may well depend on signals from other cell-types (Bhat et al., 1981; Bologa et al., 1982; Mithen et al., 1983). It seems likely that central myelination requires signals derived from neuronal perikarya and/or their axons, similar to what has been shown for Schwann cells in the periferal nervous system (Wood and Bunge, 1975).

Ideally, our chemically defined medium should select only for the survival of oligodendrocytes and prevent any proliferation of other cell types (cf. Barnes and Sato, 1980). From that point of view the chemically defined medium described in Table $I$ is not selective for the growth of oligodendrocytes because astrocytes do still proliferate, although their growth is substantially restricted compared to cultures in serum-containing medium. In order to block astrocyte proliferation, we have added cytosine-1- $\beta$-D-arabinofuranoside (Ara-C), an inhibitor of mitosis, to the culture medium after 2 days in vitro. Addition of Ara-C before this time resulted in a much lower yield of oligodendrocytes (results not shown), indicating that oligodendrocytes or their precursor cells are still mitotic.

We found little effect of leaving out any of the individual components of the CDM (Table 1), with the exception of transferrin and insulin. This might indicate a cooperative effect of the components of the CDM (cf. Morrison and de Vellis, 1981; Michler-Stuke and Bottenstein, 1982). The absence of serum, however, appears to be the crucial factor responsible for the successful maintenance of intact oligodendrocytes. It is interesting to note in this context that the absence of serum may be the determining factor in the development of a bipotential glial precursor cell into an oligodendrocyte as has been reported by Raff et al. (1983).

\section{Acknowledgements}

Gifts of anti-myelin basic protein serum by Dr. S.E. Pfeiffer and anti-glial fibrillary acidic protein serum by Dr. A. Schousboe are gratefully acknowledged. We thank Ms. E.C. Zeinstra and Mr. A.J. van der Molen for their skillful technical assistance. This work was supported in part by the Netherlands Foundation of Chemical Research (S.O.N.) with financial aid from the Netherlands Organization for the Advancement of Pure Research (Z.W.O.) and by the Prinses Beatrix Fonds.

\section{References}

Abney, E.R., Bartlett, P.P. and Raff, M.C. (1981) Astrocytes, ependymal cells, and oligodendrocytes develop on schedule in dissociated cell cultures of embryonic rat brain, Develop. Biol., 83: 301-310.

Barnes, D. and Sato, G. (1980) Methods for growth of cultured cells in serum-free medium, Analyt. Biochem., 102: 255-270.

Bhat, S., Barbarese, E. and Pfeiffer, S.E. (1981) Requirement for non oligodendrocyte cell signals for enhanced myelinogenic gene expression in long-term cultures of purified rat oligodendrocytes, Proc. nat. Acad. Sci. U.S.A., 78: 1283-1287.

Bologa, L., Siegrist, H.-P. and Herschkowitz, N. (1981) Relative changes in the amount of galactocerebroside during development as observed in mouse brain cell cultures, Neurosci. Let1., 26: 335-339. 
Bologa, L., Bisconte, J.-C., Joubert, R., Marangos, P.J., Derbin, C., Rioux, F. and Herschkowitz, N. (1982) Accelerated differentiation of oligodendrocytes in neuronal-rich embryonic mouse brain cell cultures, Brain. Res., 252: 129-136.

Bottenstein, J.E. and Sato, G.H. (1979) Growth of a rat neuroblastoma cell line in serum-free supplemented medium, Proc. nat. Acad. Sci. U.S.A., 76: 514-517.

Brunner, G., Lang, K., Wolfe, R.A., McClure, D.B. and Sato, G.H. (1982) Selective cell culture of brain cells by serum-free, hormone-supplemented media: a comparative morphological study, Develop. Brain. Res., 2: 563-575.

Chao, S.-W. and Rumsby, M.G. (1977) Preparation of astrocytes, neurons and oligodendrocytes from the same rat brain, Brain Res., 124: 347-351.

Chen, R.F. (1967) Removal of fatty acids from serum albumin by charcoal treatment, J. biol. Chem., 242: $173-181$.

Fewster, M.E., Blackstone, S.C. and Ihrig, T.J. (1973) The preparation and characterization of isolated oligodendroglia from bovine white matter, Brain Res., 63: 263-271.

Gebicke-Harter, P.J., Althaus, H.-H., Schwartz, P. and Neuhoff, V. (1981) Oligodendrocytes from postnatal cat brain in cell culture, Develop. Brain Res., 1: 497-519.

Hansson, E., Sellström, Å., Persson. L.I. and Rönnbäck. L. (1980) Brain primary culture--a characterization, Brain Res., 188: 233-246.

Hansson, E., Rönnbäck, L., Lowenthal, A., Noppe, M., Alting, C., Karlsson, B. and Sellström, Á. (1982) Brain primary culture - a characterization (Part II), Brain Res., 231: 173-183.

Hirayama, M., Silberberg, D.H., Lisak, R.P. and Pleasure, D. (1983) Long-term culture of oligodendrocytes isolated from rat corpus callosum by Percoll density gradient, J. Neuropath. exp. Neurol., 42: $16-28$.

Honneger, P., Leloir, D. and Farrod, P. (1979) Growth and differentiation of aggregating fetal brain cells in a serum-free defined medium, Nature (Lond.), 282: 305-307.

Lisak, R.P., Pleasure, D.E., Silberberg, D.H., Manning, M.C. and Saida, T. (1981) Long term culture of bovine oligodendroglia isolated with a Percoll gradient, Brain Res., 223: 107-122.

Lowry, O.H., Rosebrough, N.J., Farr, A.L. and Randall, R.J. (1951) Protein measurement with the Folin phenol reagent, J. biol. Chem., 193: 265-275.

McCarthy, K.D. and de Vellis, J. (1980) Preparation of separate astroglial and oligodendroglial cell cultures from rat cerebral tissue. J. Cell Biol., 85: 890-902.

Michler-Stuke, A. and Bottenstein, J.E. (1982) Proliferation of glial-derived cells in defined media, J. Neurosci. Res., 7: 215-228.

Mirsky, R., Winter, J., Abney, E.R., Pruss, R.M., Gavrilovich, J. and Raff, M.C. (1980) Myelin-specific proteins and glycolipids in rat Schwann cells and oligodendrocytes in culture, J. Cell Biol., 84: $483-494$.

Mithen, F.A., Wood, P.M., Agrawal, H.C. and Bunge, R.P. (1983) Immunohistochemical study of myelin sheaths formed by oligodendrocytes interacting with dissociated dorsal root ganglion neurons in culture, Brain Res., 262: 63-69.

Morrison, R.S. and De Vellis, J. (1981) Growth of purified astrocytes in a chemically defined medium, Proc. nat. Acad. Sci. U.S.A., 78: 7205-7209.

Nishizawa, Y., Kurihara, T. and Takahashi, Y. (1981) Immunohistochemical localization of $2^{\prime}-3^{\prime}$-cyclic nucleotide 3'-phosphodiesterase in the central nervous system, Brain Res., 212: 219-222.

Norton, W.T, (1983) Recent advances in the neurobiology of oligodendroglia. In S. Fedoroff and L. Hertz (Eds.), Advances in Cellular Neurobiology, Vol. 4, Academic Press, New York, pp. 3-55.

Pfeiffer, S.E., Barbarese, E. and Bhat, S. (1981) Noncoordinate regulation of myelogenic parameters in primary cultures of dissociated fetal rat brain, J. Neurosci. Res., 6: 369-380.

Poduslo, S.E. and Norton, W.T. (1972) Isolation and some chemical properties of oligodendroglia from calf brain, J. Neurochem., 19: 727-736.

Raff, M.C., Miller, R.H. and Noble, M. (1983) A glial progenitor cell that develops in vitro into an astrocyte or an oligodendrocyte depending on culture medium, Nature (Lond.), 303: 390-396.

Romijn, H.J., Habets, A.M.M.C., Mud, M.T. and Wolters, P.S. (1982) Nerve outgrowth, synaptogenesis and bioelectric activity in fetal rat cerebral cortex tissue cultured in serum-free, chemically defined medium, Develop. Brain Res., 2: 583-589. 
Sims, N.R. and Carnegie, P.R. (1978) 2',3'-Cyclic nucleotide 3'-phosphodiesterase. In B.W. Agranoff and M.H. Aprison (Eds.), Advances in Neurochem., Vol. III, Plenum Press, New York, pp. 1-41.

Snyder, E.Y. and Kim, S.U. (1979) Hormonal requirements for neuronal survival in vitro, Neurosci. Lett., 13: $225-230$.

Snyder, D.S., Raine, C.S., Farooq, M. and Norton, W.T. (1980) The bulk isolation of oligodendroglia from whole rat forebrain: a new procedure using physiologic media, J. Neurochem., 34: 1614-1621.

Sprinkle, T.J., Wells, M.R., Garver, F.A. and Smith, D.B. (1980) Studies on the Wolfgram high molecular weight CNS myelin proteins: relationship to $2^{\prime}, 3^{\prime}$-cyclic nucleotide $3^{\prime}$-phosphodiesterase, J. Neurochem., 35: 1200-1208.

Szuchet, S., Arnason, B.G.W. and Polak, P.E. (1978) A new method for oligodendrocyte isolation, Biophys. J., 21: 51 a.

Wood, P.M. and Bunge, R.P. (1975) Evidence that sensory axons are mitogenic for Schwann cells, Nature (Lond.), 256: 662-664.

\section{Note added in proof}

Recently, a similar method was reported for the isolation of oligodendrocytes from whole rate brain using a Percoll gradient: L.N. Berti Mattera, J.N. Larocca, A. Pellegrino de Iraldi, J.M. Pasquini and E.F. Soto (1984), Neurochem. Int., 6: 41-50. 